\title{
Management of White Mold Fungus Sclerotinia sclerotiorum (Lib) De Bary Causes Disease in Tomato under In vitro Conditions
}

\author{
N. K. Upadhyay ${ }^{1 *}$, Ved Ratan', V. K. Yadav ${ }^{2}$, Ajay Kumar $^{2}$, Deepak Awasthi', \\ Subhash Chandra ${ }^{2}$ and Jai P. Rai ${ }^{3}$

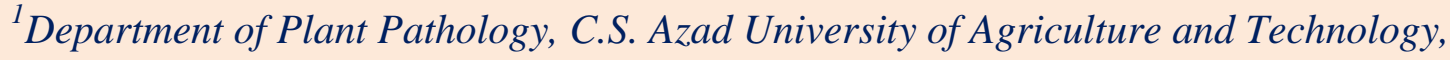 \\ Kanpur-222131(UP), India \\ ${ }^{2}$ Department of Plant Pathology, N.D.U.A. \& T., Kumarganj, Ayodhya-224229 (UP), India \\ ${ }^{3}$ Krishi Vigyan Kendra, Inst. of Ag. Sci., RGSC, BHU, Barkachha, Mirzapur 231001, \\ $U P$, India \\ *Corresponding author
}

\section{A B S T R A C T}

Tomato crop affected by different fungal diseases in which Fruit rot known as target spot disease incited by Sclerotinia sclerotiorum is one of the most destructive disease. Disease severity varied (30.50 to $18.60 \%)$ in different locations of Kanpur. Highest disease severity

\section{Keywords}

Sclerotinia, management, white mould, in vitro, tomato

\section{Article Info}

Accepted:

22 July 2019

Available Online:

10 August 2019 was $(30.50 \%)$ and the lowest disease severity $(18.60 \%)$ was noticed at the farmer's field of Billhore, Kanpur. Sclerotinia sclerotiorum is a soil borne pathogen which causes symptoms on ripe fruits. Pathogen isolated from infected fruits. Copper oxychloride, Kavach, Tebucanazol, Andrachite, Dithane M-45, Metalaxyl, Roko and Bavistin completely suspected the growth of pathogenin vitro. Among eight fungicides, Tebuconazol, Andrachite, Metalaxyl, Roko, and Bavistin were found effective against pathogen under in vitro and in vivo conditions. However, seven bio-agents (Trichoderma spp.), T. koningii, T. virensare found effective in bothconditions. In vitro eight fungicides were tested against pathogen in which Metalaxyl, Roko, Tebucanazol, Andrachite and Bavistin showed $100 \%$ growth inhibition. Seven bio-agents (Trichodermaspp.) were tested in vitro while, among them $T$. koningii showed maximum inhibition followed by $T$. virens, T. longibrachiatum, T. atroviridae, $T$. asperallum, $T$. viridae and $T$. reesei, respectively. Eight treatments were applied in vivo for disease management however, among them $\mathrm{T}_{6}$ (Bacillus subtilis + bavistin) recorded the minimum disease incidence and maximum fruit yield.

\section{Introduction}

Sclerotinia sclerotiorum (Lib.) is a serious fungus affecting yield and product quality of many susceptible hosts. It is a widespread soil borne plant pathogen with an extremely wide host range of more than 400 plant species including many of economic importance (Gao et al., 2014). S. sclerotiorum is responsible for more than 60 plant diseases (Purdy, 1979). The pathogen produces sclerotia, which survive for long periods and attackroots of growing and mature plants, resulting in root rot, basal stemcanker, and wilt (Duncan et al., 
2006). Sclerotinia Stem Rot (also known as white mold or Sclerotinia Stem and Root Rot) is one of the most important tomato soil borne diseases. Plant infection occurs either by myceliogenic germination of sclerotia or by ascospores released from apothecia during carpogenic germination of sclerotia. The myceliogenically germinating sclerotia are the main source of infection on processing tomato crops leading to rotting of aerial parts of the plant in contact with soil (Gao et al., 2014; Purdy, 1979). Crop rotation and cultural methods are not sufficiently effective in controlling Sclerotinia Stem Rot disease because of pathogen's large host range including weeds, its ability to survive as sclerotia, and possible plant infection by airborne ascospores released from germinating sclerotia in nearby infected fields (Elkahoui et al., 2014). Thus, the biological, plant extracts and fungicidal management may be effective in controlling disease.

Tomato is also well known as productive food. In India production of tomato during 2016-17 was 196.96lakh tones and total area under tomato production was 809.0 ha. This constitutes 10.8 per cent of total vegetable area and $12.2 \%$ of total vegetable production. The productivity of tomato in India is 24.4 MT/ha during 2016-17 which is very low as compare to other countries of the world like USA, 84.0 tones /ha (NHB, 2017).

One of main reason of low productivity of tomato in India is diseases which are caused by fungi, bacteria, virus, nematode and abiotic factors (Naema et al., 2016). It was well known that the pathogen of white mould could survive on the infected seeds for several days. The study was undertaken with entitled "management of white mould fungus Sclerotinia sclerotiorum (Lib.) de Bary causes disease in tomato under in vitro" to find out and development of suitable strategies for disease management.

\section{Materials and Methods}

Survey for ascertaining the incidence of fruit rot of tomato was carried out at regular interval during Rabi crop season 2015-16 at vegetable research farm, Kalyanpur, Chandra Shekhar Azad University of agriculture and technology, Kanpur and its adjacent areas from where diseased samples were collected for further studies.

The diseased specimens were brought to the laboratory and critically examined for the presence of causal organism. These specimens were used for isolation of the pathogen in culture, preserved, labelled and kept in dry and wet forms for further investigations and record.

\section{Pathogenicity test}

The pathogenicity of the isolated fungus was conducted on Healthy stems of host plant in order to establish the pathogenic nature of the fungus. The pathogenicity of the fungus was tested according to Koch's Postulate's (1882). The sterilized healthy seeds of tomato were grown in earthen pots of $25 \mathrm{~cm}$ diameter containing sterilized soil. Mycelial discs of 5.0 $\mathrm{mm}$ diameter were used from the margin of 7 days old culture grown on 20per cent potato dextrose agar medium, and were placed at the base of one month old injured and uninjured healthy tomato plants, already washed with sterilized water.

The homogenized $200 \mathrm{ml}$ mycelial suspension was prepared in sterilized water with 7 days old culture. The inoculated plants were covered with polythene bags for 48 hrs to create the humidity for infection. In this method the pots were shifted to the glass house just after inoculation, where they were watered periodically to maintain sufficient moisture to proper growth of plants for disease development. 
Screening of chemical fungicide against the pathogen in vitro

Eight chemical fungicides viz., Copper oxychloride, Kavach, Tebucanazole, Andrachite, Dithane M-45, Metalaxyl, Roko, and Bavistin belonging to different groups were evaluated against the pathogen under laboratory condition to find out their relative efficacy in inhibiting the growth of the pathogen in culture by the Food Poison Technique (Schmitz, 1930). Requisite quantity of each fungicide was incorporated in two per cent potato dextrose agar medium and thoroughly mixed by shaking prior to pouring in sterilized Petri plates. The medium was allowed to solidify and then inoculated with 5 $\mathrm{mm}$ disc of inoculums from seven days old culture of the pathogen. The fungal discs were reversed so that the pathogen could come in contact with the medium, directly. Three replications were made for each treatment. The Petri plates were incubated at $20 \pm 1{ }^{0} \mathrm{C}$ with one set of control in which the medium was not mixed with any fungicide but simply inoculated with pathogen. The data on radial growth of fungal colony measured till the control plates were not filled up. The per cent inhibition over control was calculated by the following formula (Bliss, 1934).

Per cent inhibition over control $=\frac{\mathrm{C}-\mathrm{T}}{\mathrm{C}} \times 100$

Where,

$\mathrm{C}=$ Growth of fungus in control (mm)

$\mathrm{T}=$ Growth of fungus in treatment $(\mathrm{mm})$

Screening of bio-agents (Trichoderma spp.) against the pathogen in vitro

This experiment was done with seven isolates of different bio-agents viz., Trichoderma viridae, T. longibrachiatum, $T$. reesei, $T$. koningii, T. asperallum, T. atroviridae, T. virens were evaluated by dual culture techniques to find out the efficacy of bioagents against the pathogen. Discs of $5 \mathrm{~mm}$ diameter were taken from the actively growing colonies of the test pathogen and antagonists with the help of sterilized cork borer. The discs of the pathogen and antagonists were placed on the other side in agar plates aseptically. The discs of antagonists were placed on the other side at about $30-40 \mathrm{~mm}$ distance of pathogen in same plates. The plates were incubated at $20 \pm 1{ }^{\circ} \mathrm{C}$, after 6 days of incubation the mechanism of interaction was observed and the data were expressed as per cent inhibition by following formula.

Growth in control (mm) -

Growth in treatment $(\mathrm{mm})$

Per cent inhibition (P.I) $=-\times 100$

Growth in control (mm)

\section{Effect of chemical fungicides and bio-agents in vivo}

This parameter of treatments was applied to find out the efficacy of those chemical fungicides and bio-agents which showed highly effective against the pathogen in vivo. A field trial was conducted in Glass house compound, Department of Plant Pathology C. S. Azad University of Agriculture and Technology, Kanpur in 2015-16. The experiment was conducted with 8 treatments viz., $\mathrm{T}_{1}=$ Foliar application with Bacillus subtillis, $\quad \mathrm{T}_{2}=$ Seed treatment with Trichoderma spp., $\mathrm{T}_{3}=$ Foliar application with Roko (Thiophanate methyl), $\mathrm{T}_{4}=$ Seed treatment with Bavistin, $\mathrm{T}_{5}=$ Bacillus subtillis + Roko, $\mathrm{T}_{6}=$ Bacillus subtillis + Bavistin, $\mathrm{T}_{7}=$ Trichoderma + Roko and $\mathrm{T}_{8}=$ Trichoderm $a+$ Bavistin in 3 replications and plot size was $2.50 \times 1.50$ square meters. The observation on total fruit per plant was count in each treatment. The disease incidence was calculated by formula given below: 
Disease incidence

$\frac{\text { No of infected plant per plot }}{\text { Total plant per plat }} \times 100$

\section{Results and Discussion}

For ascertaining disease incidence, survey was conducted at different localities in Kanpur during crop season in the month of January 2016. The diseased plants were collected for isolation for further studies. It is obvious from the data presented in table 1 that the disease severity varied from 30.50 to 18.60 per cent in different locations. However, it was highest (30.50) at vegetable research farm, Kalyanpur, Kanpur. The lowest disease severity was noticed at the farmer fields at Billhore, Kanpur.

\section{Pathogenicity test of the pathogen}

To ascertain the pathogenicity of the isolated fungus, one month old plants of tomato cultivar (T-4) was preferred as test plant and the result revealed that the infection of plants with mycelia suspension proved to be the best
$=$ method of infection whereas inoculation with sclerotia showed poor infection among the methods tried. Reisolation of the fungus was done from inoculated plants. In each case, it was found that infection per cent was more in injured fruit than the uninjured ones, which suggested that injury on the fruit facilitate the pathogen for easy and quick infection. After three days of inoculation of pathogen, symptoms produced in the form of small, brown, water soaked lesions on the fruit which finally turned into brown in colour.

The symptoms observed were similar to those as observed under natural conditions in all the respect. Reisolation from artificially inoculated plant was done and the yield of same fungus Sclerotinia sclerotiorum was found like previously isolated from naturally infected tomato plants. In this way isolation, inoculation and re-isolations proved the Koch's postulates, as this pathogen is capable of attacking both the injured and uninjured, it proved that Sclerotinia sclerotiorum is a potential pathogen of tomato.

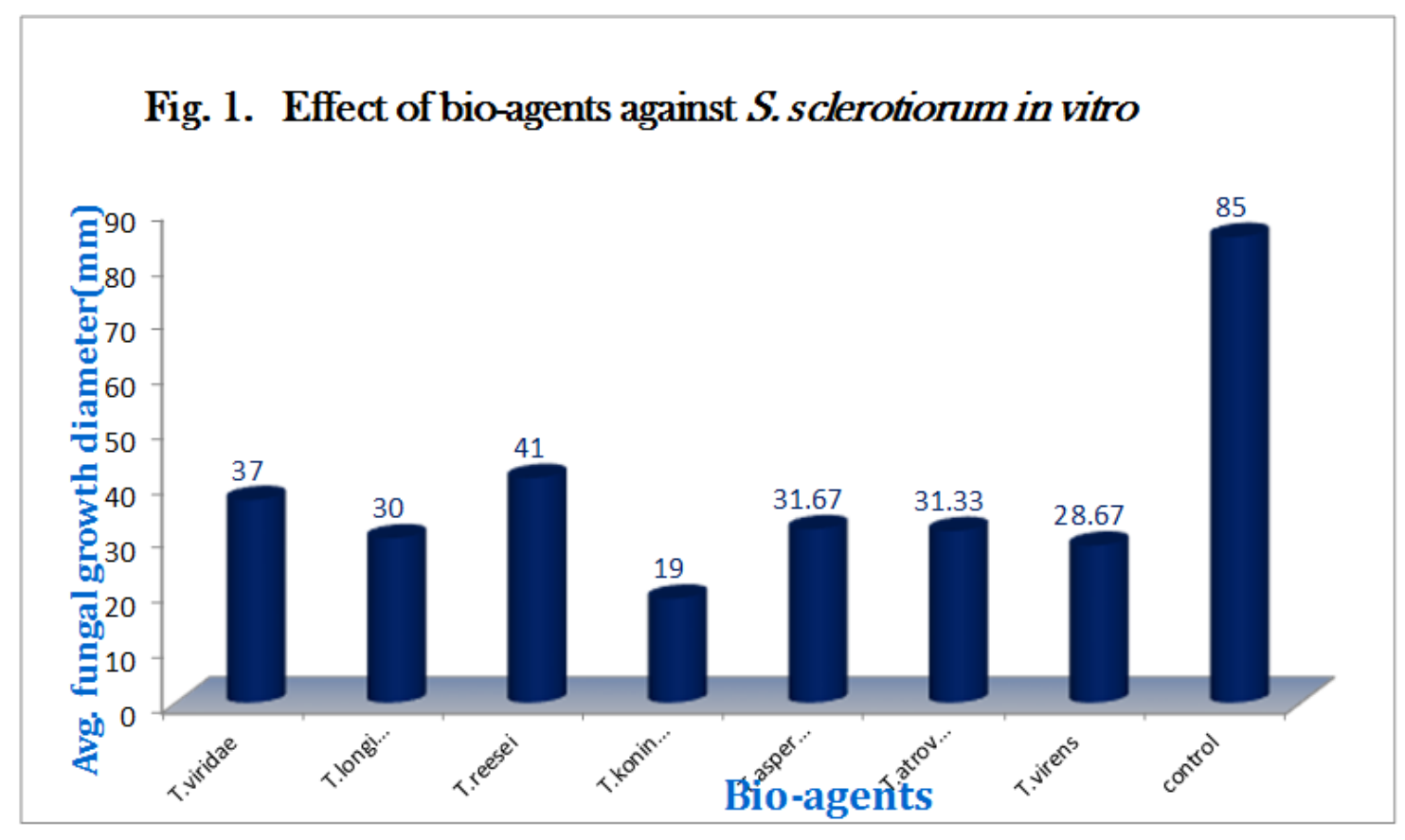


Fig. 2. Effect of chemical fungicides against $S$. sclerotionum in vitro

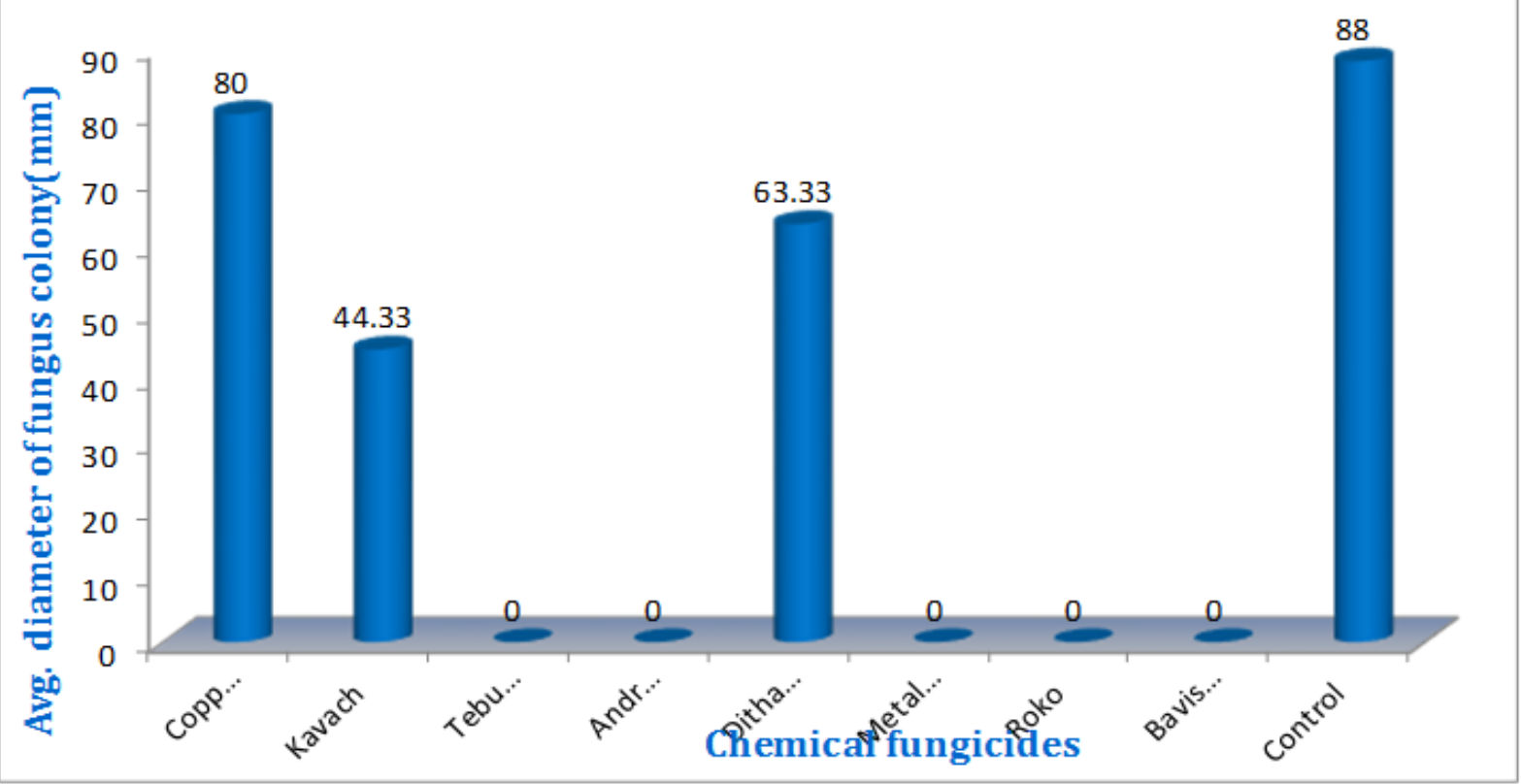

Fig. 3. Effect of incidence and yield of $S$. sclerotiorum in vivo

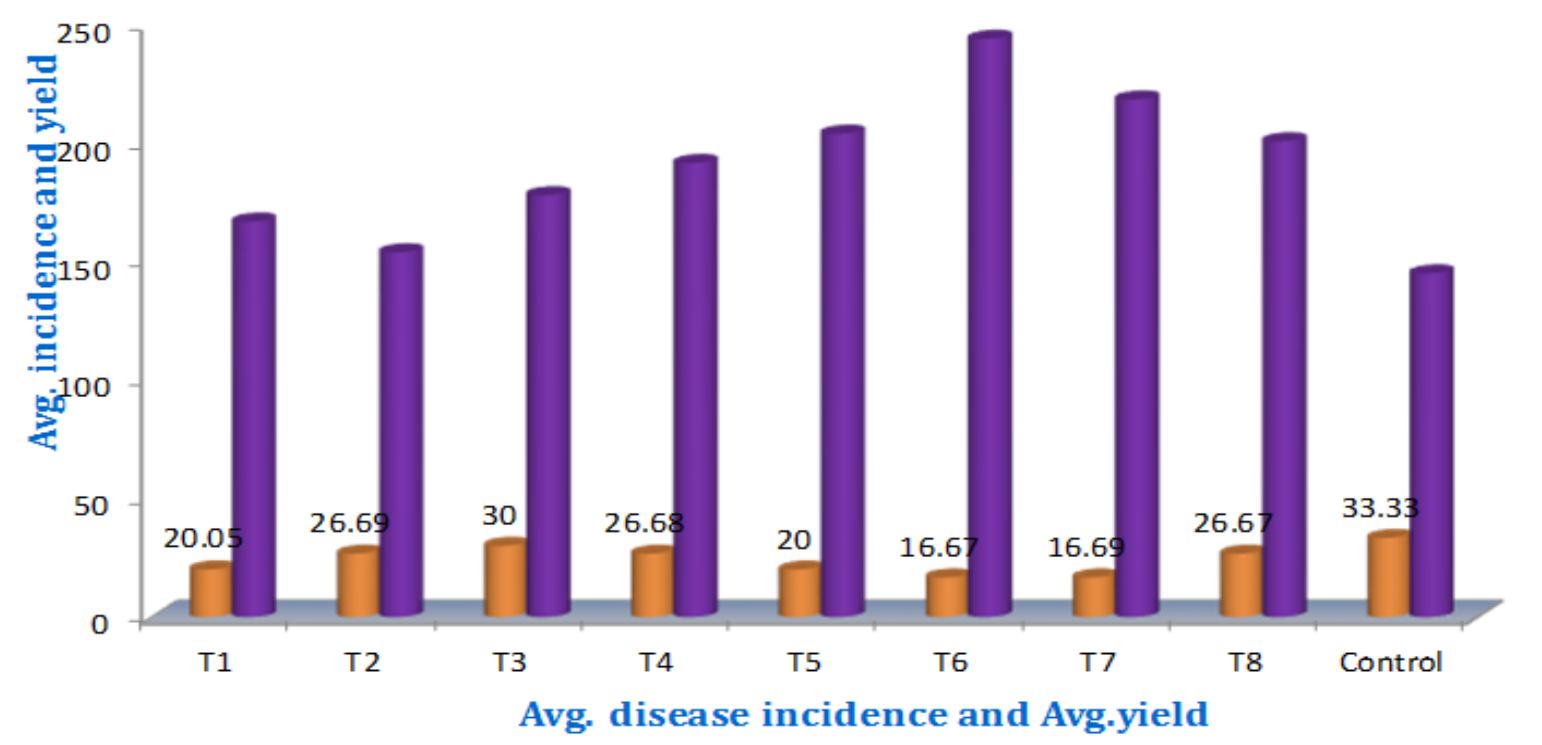



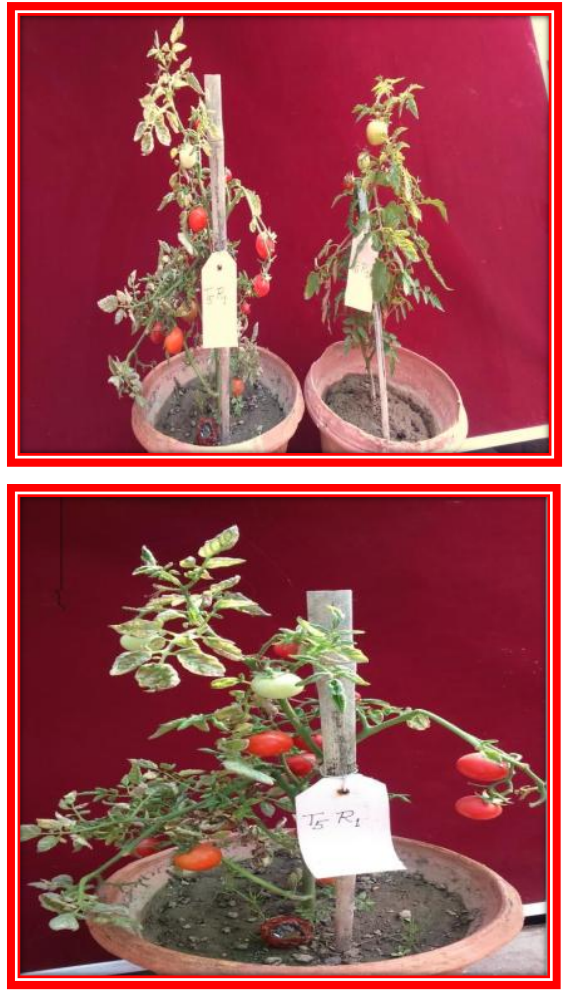

Plate 1. Pathogenicity test of the pathogen
A. Inoculated

B. Uninoculated
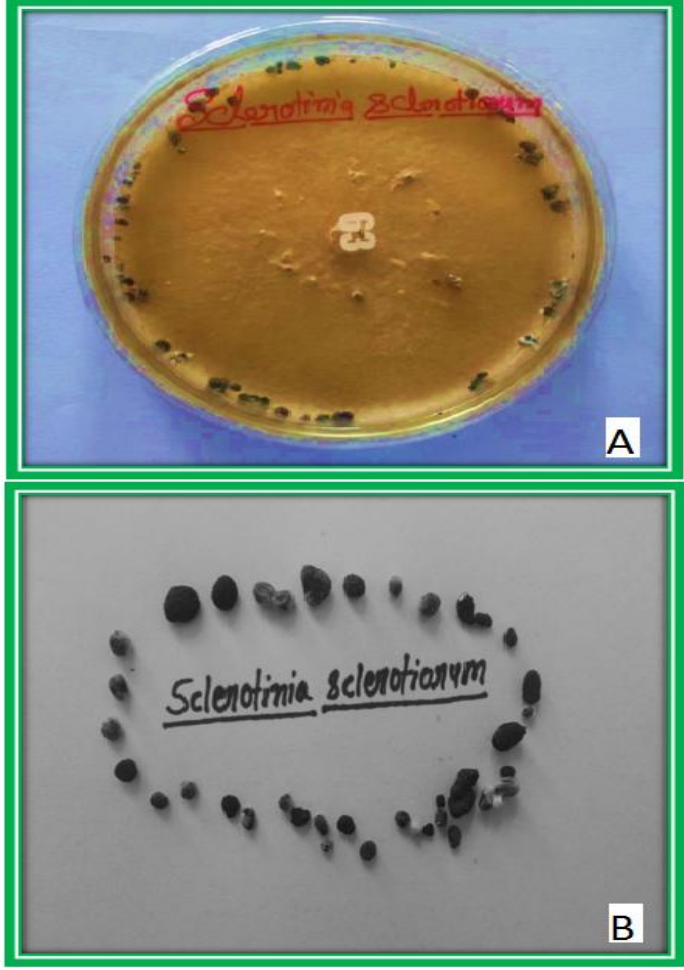

Plate 2. Identification of the pathogen

A. Growth of S. sclerotiorum on PDA medium

B. Sclerotia of S. sclerotiorum

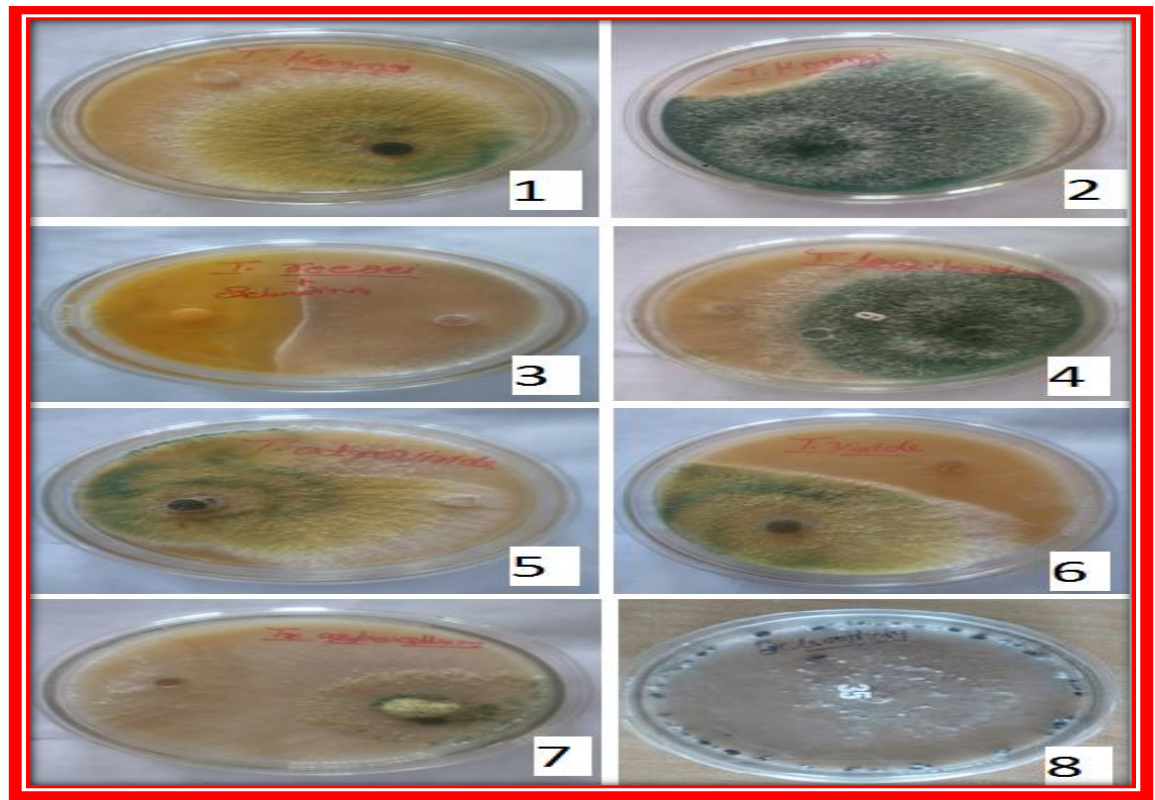

Plate.3 Effect of bio-agents against S. sclerotiorum in vitro

$\mathbf{T}_{1-}$ Trichoderma koningii, $\mathbf{T}_{2}-$ T. virens, $\mathbf{T}_{3^{-}}$T. ressei, $\mathbf{T}_{4}-$ T. longibrachiatum

$\mathbf{T}_{5^{-}}$T. atroviridae, $\mathbf{T}_{6^{-}}$T. viridae, $\mathbf{T}_{7^{-}}$T. asperallum, $\boldsymbol{T}_{8^{-}}$Control 


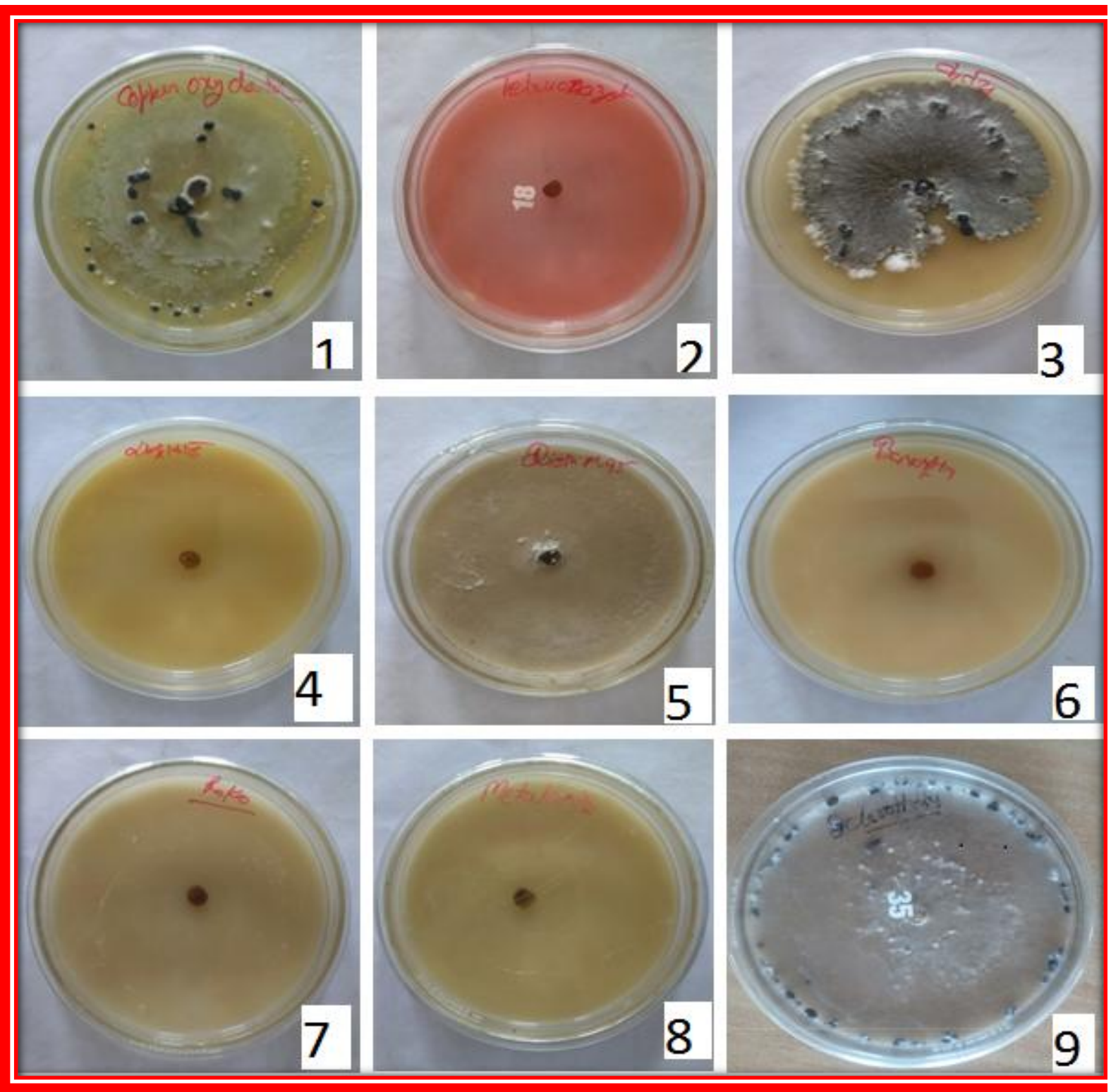

Plate 4. Effect of chemical fungicides against $S$. sclerotiorum in vitro.

$\mathrm{T}_{1^{-}}$Copper oxychloride, $\mathrm{T}_{2^{-}}$Tebucanazole, $\mathrm{T}_{3^{-}}$Kavach, $\mathrm{T}_{4^{-}}$Andrachite $\mathrm{T}_{5}$ - Dithane M-45 $\mathrm{T}_{6}$ - Bavistin, $\mathrm{T}_{7}-$ Roko, $\mathrm{T}_{8}-$ Metalaxyl, $\mathrm{T}_{9}$ - Control

Table.1 Incidence of white mold of Tomato at different localities of Kanpur

\begin{tabular}{|c|l|c|}
\hline Sr. No. & Locality & $\begin{array}{c}\text { Average disease } \\
\text { incidence (per cent) }\end{array}$ \\
\hline 1. & Vegetable Research Farm Kalyanpur, Kanpur & 30.50 \\
\hline 2. & Student Instructional Farm, C S A UNIV. Kanpur & 22.30 \\
\hline 3. & Farmers field, Billhore, Kanpur (city) & 18.60 \\
\hline
\end{tabular}


Table.2 Pathogenicity of the fungus exhibited through different method of inoculation

\begin{tabular}{|l|l|l|l|l|}
\hline $\begin{array}{l}\text { Sr. } \\
\text { No. }\end{array}$ & Treatment & $\begin{array}{l}\text { No. of plant } \\
\text { subjected } \\
\text { infection }\end{array}$ & $\begin{array}{l}\text { No. of plant } \\
\text { to } \\
\text { showing disease } \\
\text { symptoms }\end{array}$ & $\begin{array}{l}\text { Per cent } \\
\text { infection }\end{array}$ \\
\hline $\mathbf{1 .}$ & $\begin{array}{l}\text { Inoculation with } \\
\text { disc of the } \\
\text { fungus } \\
\text { (i) infected } \\
\text { (ii) Uninfected }\end{array}$ & 25 & & \\
\hline $\mathbf{2 .}$ & $\begin{array}{l}\text { Inoculation with } \\
\text { mycelial } \\
\text { suspension } \\
\text { (i) infected } \\
\text { (ii) Uninfected }\end{array}$ & 25 & 20 & 80 \\
\hline $\mathbf{3 .}$ & 25 & 13 & 52 \\
\hline & $\begin{array}{l}\text { Inoculation with } \\
\text { sclerotia } \\
\text { (i) infected } \\
\text { (ii) Uninfected }\end{array}$ & 25 & 23 & 92 \\
\hline
\end{tabular}

Table.3 Effect of bio-agent on the growth of S. sclerotiorum in vitro

\begin{tabular}{|l|l|c|c|}
\hline Sr. No. & Bio-agents & $\begin{array}{l}\text { Avg. radial growth of the } \\
\text { pathogen }(\mathbf{m m})\end{array}$ & $\begin{array}{l}\text { Percent inhibition } \\
\text { over control }\end{array}$ \\
\hline $\mathbf{1 .}$ & T. viridae & 37.00 & 56.47 \\
\hline 2. & T. longibrachiatum & 30.00 & 64.70 \\
\hline $\mathbf{3 .}$ & T. reesei & 41.00 & 51.76 \\
\hline $\mathbf{4 .}$ & T. koningii & 19.00 & 77.64 \\
\hline $\mathbf{5 .}$ & T. asperallum & 31.60 & 62.82 \\
\hline 6. & T. atroviridae & 31.33 & 63.14 \\
\hline 7. & T. virens & 28.66 & 66.28 \\
\hline 8. & Control & 85.00 & - \\
\hline & CD at 5\% & $\mathbf{3 . 8 5}$ & \\
\hline
\end{tabular}


Table.4 Inhibitory effect of chemical fungicides on the growth of S. sclerotiorum in vitro

\begin{tabular}{|c|c|c|c|c|}
\hline Sr. No. & Fungicides & $\begin{array}{l}\text { Dose per } \\
\text { cent }\end{array}$ & $\begin{array}{lrr}\begin{array}{l}\text { Av. diameter } \\
\text { fungal }\end{array} & \text { of } \\
(\mathrm{mm}) & & \end{array}$ & $\begin{array}{l}\begin{array}{l}\text { Inhibition } \\
\text { control } \\
\text { cm.) }\end{array} \\
\text { (per }\end{array}$ \\
\hline 1. & Copper oxychloride & 0.10 & 80.00 & 9.09 \\
\hline 2. & Kavach & 0.10 & 44.33 & 49.62 \\
\hline 3. & Tebucanazol & 0.10 & 00 & 100.00 \\
\hline 4. & Andrachite & 0.10 & 00 & 100.00 \\
\hline 5. & Dithane M-45 & 0.10 & 63.33 & 23.03 \\
\hline 6. & Metalaxyl & 0.10 & 00 & 100.00 \\
\hline 7. & Roko & 0.10 & 00 & 100.00 \\
\hline 8. & Bavistin & 0.10 & 00 & 100.00 \\
\hline 9. & Control & - & 88 & - \\
\hline & $\mathrm{CD}$ at $5 \%$ & & 2.53 & \\
\hline
\end{tabular}

Table.5 Per cent disease incidence and yield in vivo

\begin{tabular}{|l|l|l|l|}
\hline Sr. No. & Treatment & $\begin{array}{l}\text { Avg. per cent } \\
\text { disease incidence }\end{array}$ & $\begin{array}{l}\text { Avg. yield (in } \\
\text { quintal per ha.) }\end{array}$ \\
\hline $\mathbf{1 .}$ & Foliar appli. with Bacillus subtilis & 20.05 & 166.66 \\
\hline $\mathbf{2 .}$ & Seed tr. withTrichoderma spp. & 26.69 & 153.70 \\
\hline $\mathbf{3 .}$ & Foliar appli. With rook & 30.00 & 177.77 \\
\hline $\mathbf{4 .}$ & Seed tr. withbavistin & 26.68 & 191.35 \\
\hline $\mathbf{5 .}$ & Bacillus subtilis + roko & 20.00 & 203.70 \\
\hline $\mathbf{6 .}$ & Bacillus subtilis +bavistin & 16.67 & 243.70 \\
\hline $\mathbf{7 .}$ & Trichoderma+roko & 16.69 & 218.14 \\
\hline $\mathbf{8 .}$ & Trichoderma+bavistin & 26.67 & 200.49 \\
\hline & Control & 33.33 & 144.81 \\
\hline & CD at 5\% & $\mathbf{1 3 . 4 5}$ & $\mathbf{1 1 . 8 5}$ \\
\hline
\end{tabular}

Screening of bio-agents against $S$. koningii (77.64\%)followed by $T$. Virens sclerotiorum (66.28\%), T. longibrachiatum (64.70\%), T. Atroviridae $(63.14 \%), \quad T$. asperallum Seven different Bio-control agents viz.; $T$. viridae, T. longibrachiatum, $T$. reesei, $T$. koningii, T. asperallum, T. atroviridae, and T. virens were evaluated in vitro by dual culture technique for the biological management of the disease. The results are presented in Table 3 , plate 1 and its corresponding graph (fig.1) indicated that all the bio-agents suppressed the colony growth of Sclerotinia sclerotiorum. The suppression of growth of pathogen was maximum with Trochoderma (62.82\%), T. viridae $(56.47 \%)$ and the least effective bio-agent was $T$. reesei $(51.76 \%)$. These findings are in accordance of Naema $e t$ al., (2016); Abdel-Kader et al., (2012); Abo rehab et al., (2013).

Evaluation of chemical fungicides against S. sclerotiorum

A preliminary screening of 8 chemicals belonging different groups were done. 
Thedose of fungicides was used based on the preparatory formulation of each fungicide. Growth of the pathogen was measured and average diameter of colony in each petri dish was recorded. Per cent inhibition over control was calculated separately for each treatment and results are presented in Table 4, plate 4 and its corresponding graph (fig. 2) indicated that all tested fungicides showed there better response in minimizing the radial growth of pathogen over control. Hundred per cent radial growth of fungus was checked with Tebucanazole, Andrachite, Metalaxyl, Roko and Bavistin followed by Kavach (49.62\%) and Dithane M-45 (23.03\%). However, the maximum radial growth was observed with copper oxychloride $(80 \mathrm{~mm})$. These results are in collaboration with Abdel-Kader et al., (2013) found that, combination of(compost + $T$. harzianum + thyme) and (compost $+T$. harzianum+ lemongrass) reduced the peanut crownrot disease incidence at both pre- and post-emergence growth stages, respectively compared with Vitavax-Captan at $3 \mathrm{~g} / \mathrm{kg}$ and untreated control.

\section{Effect of chemical fungicides and bio- agents in vivo}

In order to know impartial treatment on per cent disease incidence on field and yield per plant in tomato (T-4) was observed and efficacy of different treatment against test pathogen was also recorded and summarised in table 5 with its corresponding graph (Fig. 3). All treatments showed better response in minimizing the disease incidence as well as increasing the yield over control. The minimum disease incidence above as $16.67 \%$ in $\mathrm{T}_{6}$ (Bacillus subtilis + bavistin) which gave maximum yield $(243.70 \mathrm{q} / \mathrm{ha})$ was recorded followed by $\mathrm{T}_{7}$ (Trichoderma + roko) showed the disease incidence $16.69 \%$ and found the yield $218.14 \mathrm{q} / \mathrm{ha}$. However, the maximum disease incidence $(30 \%)$ was in $\mathrm{T}_{3}$ (Foliar application with roko) and minimum yield was recorded $153.70 \mathrm{q} / \mathrm{ha}$ in $\mathrm{T}_{2}$ (seed treatment with Trichoderma). Eisa et al., (2013) recorded that, underfield conditions combining the fungicide Folicur with compost has enhanced the control of white rot ofonion and bulb yield compared with using alone. These findings are in collaboration with the findings of other workers (Pane et al., 2013; Elkahoui et al., 2014; Naema et al., 2016) reported similar response in management of white mould fungus in vitro Conditions.

\section{References}

Abdel-Kader M.M., Abdel-Kareem F., ElMougy N.S. and El-Mohamady R.S. 2013. Integration between compost, Trichoderma harzianum and essential oils for controlling Peanut crown rot under field conditions. Journal of Mycology, pp.1-7.

Abdel-Kader M.M., El-Mougy N.S., Embaby E.I. and Lashin S.M. 2012. Occurrence of Sclerotiniafoliage blight disease of cucumber and pepper plants under protected cultivation system in Egypt. Chemical and Biological Control Measures in vitro. Advances in Life Sciences, 2(1): 20-27.

Abo Rehab M.E.A., Korra A.K.M., Kamhawy M.A.M. and Youssef K.Y.A. 2013. Fungal speciesassociated with graft union on grapevine, its impact on graft failure process and attempted solutions in Egypt. International Journal of Agriculture and Forestry, 3(2): 52-59.

Bliss C.L. 1934 The Methods of Probits. Science, 79: 38.

Duncan R.W., Dilantha Fernandoa W.G. and Rashidb K.Y. 2006. Time and burial depth influencing the viability and bacterial colonization of Sclerotinia sclerotiorum. Soil Biol Bioche., 38: 275284.

Eisa N.A., Hafez M.A., Khalifa M.M.A., Khan E.E. and Mahdy H.A.M.M. 2013. 
Effect of different types of compost in combination with some biological agents and folicur fungicide on onion white rot disease. Journal of Applied Sciences Research, 9(4): 2803-2810.

Elkahoui S., Djébali N., Karkouch I., Hadj Ibrahim A. and Kalai L. 2014. Mass spectrometry identifcation of antifungal lipopeptides from Bacillus sp. BCLRB2 against Rhizoctonia solani and Sclerotinia sclerotiorum. Appl. Biochem. Microbiol., 50: 161-165.

Gao X., Han Q., Chen Y., Qin H. and Huang L. 2014. Biological control of oilseed rape Sclerotinia stem rot by Bacillus subtilis strain Em7. Biocontrol Sci. Technol., 24: 39-52.

N.H.B. 2017. Handbook of Indian horticulture database. National Horticulture Board, Gurgaon., 177-185.

Naema A.G., Mahdy A.M.M., Fawzy R.N. and Ahmed G.A. 2016. Integrated Management of Tomato White Mold Disease Caused by Sclerotinia sclerotiorum using the Combined Treatments of Compost, Chemical Inducers and Fungicides. Middle East J. Agric. Res., 5(4): 479-486.

Pane C., Piccolo A., Spaccini R., Celano G. and Villecco D. 2013. Agricultural waste-based composts exhibiting suppressivity to diseases caused by the phytopathogenic soil-borne fungi Rhizoctonia solani and Sclerotinia minor. Appl Soil Ecol., 65: 43-51.

Purdy L.H. 1979. Sclerotinia sclerotiorum: History, diseases, symptomatology, host range, geographic distribution, and impact. Phytopathology, 69: 875-880.

Schmitaz H. 1930. A suggested toximetric method for wood preservative. Indus. and Engg. Chem. Analyst., 4: 361-363.

\section{How to cite this article:}

Upadhyay N. K., Ved Ratan, V. K. Yadav, Ajay Kumar, Deepak Awasthi, Subhash Chandra and Jai P. Rai. 2019. Management of White Mold Fungus Sclerotinia sclerotiorum (Lib) De Bary Causes Disease in Tomato under In vitro Conditions. Int.J.Curr.Microbiol.App.Sci. 8(08): 2733-2743. doi: https://doi.org/10.20546/ijcmas.2019.808.315 